\title{
Multienvironmental evaluation of wheat landraces by GGE biplot analysis for organic breeding
}

\author{
Kostas Koutis $^{1}$, Athanasios G. Mavromatis ${ }^{2^{\star}}$, Dimitrios Baxevanos ${ }^{3}$, Metaxia Koutsika-Sotiriou ${ }^{1}$ \\ ${ }^{1}$ Department of Genetics and Plant Breeding, Aristotelian University of Thessaloniki, Thessaloniki, Greece \\ ${ }^{2}$ Plant Breeding and Genetics Laboratory, University of Thessaly, Thessaly, Greece; \\ *Corresponding Author: amavromat@uth.gr \\ ${ }^{3}$ National Agricultural Research Foundation (NAGREF), Cereal Institute, Thermi, Thessaloniki, Greece
}

Received 16 October 2011; revised 20 November 2011; accepted 17 December 2011

\section{ABSTRACT}

This study was conducted to determine the performance of wheat landraces cultivated under organic conditions and to analyze their stability across diverse environments. Six wheat landraces with specific characteristics (high protein content, drought tolerance, stay green) were tested under organic growing environment. The experiments were applied in three locations (Larisa (LAR), Thessaloniki (THES), Kilkis (KIL)) for three growing seasons. The role of specific agronomic traits (stay green, lodging) and their correlation with yield components were analyzed. Stability and genotypic superiority for grain yield were determined using ANOVA and genotype $\times$ environment (GGE) biplot analysis. Furthermore, the interrelationships among wheat traits and genotype-by-trait using regression analysis, coefficient of variation and (GT)-biplot technique were studied. Significant differences were found in yield among wheat landraces tested, and also in yield components, as related to specific traits expressed into organic environment. Best varieties in terms of yield were Skliropetra and M. Argolidas, characterized by lowest weight of 1000 grains, large number of spikes per $\mathrm{m}^{2}$ meter and the highest number of grains per spike as compared to the other landraces. The statistical model GGE biplot provides useful information for experimentation of wheat landraces when grown under organic environment. It identifies clearly the ideal and representative environment for experimentation and underlines the effect of specific traits for each wheat cultivar on yield performance and stability across environments.

Keywords: Wheat; Landraces; Stay Green;
Lodging; GGE Biplot Analysis

\section{INTRODUCTION}

Wheat is the most important cereal crop and its cultivation has been related to the development of the major civilizations all over the world. Local varieties and landraces were survived from ancient years until now, expected to contribute in new practices of agriculture (sustainable or organic farming) and effects of climate changes which have adverse impacts on food production [1], food quality [2] and food security [3]. Also, the high protein content of wheat grain makes it important source of human nutrition and social economy. Unless, local varieties are not characterized by high yield and uniformity, high protein content and adaptability are their advantages for direct use in culture or as potential parental lines in wheat breeding programs. Breeding landraces, is a strategy being used to improve yield and yield stability in less favourable agricultural system with lower inputs. The stagnation of yield in these areas is mainly related to the narrow genetic base of the more recently bred, high-yielding cereal varieties [4]. For this reason the use of adapted germplasm from the crop's centres of diversity, could be useful to a successful breeding process [5].

Selection of cereal varieties appropriate for organic agriculture requires a different approach to that used when breed cereals for conventional high input systems. This is because there are fewer opportunities to compensate for limitations to yield imposed by diseases, low nutrients and weeds in organic agriculture, as well as need to adapt to highly variable environmental conditions across the diversity of organic agriculture systems [6]. According to the above discussion it is revealed that, there is a need to identify appropriate genetic resources among the older varieties or landraces either for direct use or as potential parental lines in breeding programmes for better adaption $[7,8]$. Landraces are adapted to the 
environmental conditions and agronomic practices of regions of their origin; thus, there are a valuable tool for identifying different strategies for high grain yield and adaptation [9]. Ceccarelli [10] argued that in crop plants, adaptation approximates to yield stability over time and environments. Cultivar evaluation in the presence of unpredictable GE interaction must be conducted in multiple locations to fully sample the target environment [11]. Multienvironmentl trial data are required, for estimating genotypic value and cultivar's stability for yield performance, as a tool for effective cultivar evaluation. Multienvironmental trials have, as main purpose, to identify superior cultivars for recommendation to farmers and to determine sites that best represent the target environment [12].

Wheat landraces are characterized by special features, which were shown to have positive or negative effects on yield depends on the environment of cultivation. Therefore is necessary to be recognizable and predictable when these cultivars will be grown under organic culture conditions. The aim of is provided through the following questions; How these specific traits can be interpreted under specific environments of experimentation? Can GGE biplot analysis be informative to discover the ideal environment of experimentation and reveal uncovered genotypic value of landraces based on characteristics related to high yield and adaptation in the unpredictable organic environment?

\section{MATERIALS AND METHODS}

For the purpose of this study, multienvironment trials were carried out to evaluate yield potential and stability of six wheat landraces under organic growing environments (Table 1). The experiments were applied in three locations (Larisa (LAR), Thessaloniki (THES), Kilkis (KIL)) for three growing seasons '05, '06, '07. The combinations between locations and years were equated to the appropriate number of environments (Table 1). The soil types for the three locations (Larissa, Thessaloniki, Kilkis) were C, CSL, SL and the geographical coordinates 22E25 39N38, 23E01 40N33 кal 22E52 41N00, respectively. The wheat landraces used in the experiment were selected though a 2-year study under organic growing environments with selection indices based on genotype adaptation in harsh hot and low moisture Mediterranean environment and quality characteristics of seed [13].

At each location a randomized complete bock design (RCB) with six genotypes and three replications was applied. The plot size was five rows $\times 4 \mathrm{~m}$ long $\times 0.25 \mathrm{~m}$ apart. Trials were sowing by hand after $15^{\text {th }}$ of November with a sowing rate of $200 \mathrm{Kg} / \mathrm{ha}$. Field preparation and other cultivation practices were conducted according to the protocol of growing practices for organic farming [14]. In none of the fields were applied fertilizers before installation, nor during the experiment and a two year rotation scheme was followed (winter cereal-fallow - spring leguminous - winter cereal).

Measurements and observations applied through the experiment, focused on specific agronomic characteristics (senescence/stay green at blooming stage, lodging and height at maturity stage) related to adaptation. Moreover yield components were estimated (number of spikes per $\mathrm{m}^{2}$, number of grains per spike, weight of 1000 grains) and correlated with grain yield. For all these measurements were used the three internal lines of each plot as a sampling procedure. Especially for grain yield randomly selected area of $0.50 \times 0.50 \mathrm{~m}$ was harvested, while plant height was estimated from a randomly selected sample of 10 plants per plot. These samples were taken from the three internal lines crossing points. Harvesting also was carried out manually and for threshing it was used a small scale thresher.

\section{Statistical Analysis}

Combined analysis of variance (ANOVA) across environments for grain yield and the other parameters were

Table 1. Genotypes of wheat landraces used into three organic growing testing locations for three growing seasons ('05-'07).

\begin{tabular}{|c|c|c|c|}
\hline & GENOTYPES & LOCATIONS & ENVIRONMENTS \\
\hline & & & LAR 05 \\
\hline 1 & M. AITOLOAKARNANIAS & LARISSA (LAR) & THES 05 \\
\hline 2 & SKLIROPETRA & THESSALONIKI (THES) & KIL 05 \\
\hline 3 & M. ARGOLIDAS & KILKIS (KIL) & LAR 06 \\
\hline 4 & YECORA & & THES 06 \\
\hline 5 & MEXICALI81 & & KIL 06 \\
\hline \multirow[t]{2}{*}{6} & XYLOCASTRO & & LAR 07 \\
\hline & & & KIL 07 \\
\hline
\end{tabular}


performed using the statistical softwares MSTAT (Version 1.2) and SPSS (11.5 for Windows). Cultivars were considered fixed and environments random effects. The cultivar phenotypic variance $\left(\sigma_{P}^{2}\right)$ was partitioned to its respective components, cultivar genetic variance $\left(\sigma_{g}^{2}\right)$ and cultivar by environment interaction variance $\left(\sigma_{g e}^{2^{g}}\right)$. Heritability values $h^{2}=\sigma_{g}^{2} / \sigma_{p}^{2}$ were then estimated as measure of effectiveness for differentiation among wheat cultivars to each testing environment [15]. The mean differences were estimated by LSD based on Fisher's test for $\mathrm{P}<0.05(*), \mathrm{P}<0.01(* *)$ and $\mathrm{P}<0.001(* * *)$.

The GGE biplot pattern explorer software [16] was used to: 1) evaluate the distance of environments and genotypes to an ideal 2) calculate genotypic stability and 3 ) estimate phenotypic correlations among grain yield and other parameters. The GGE biplot model, decomposes $G$ plus GE effects though the singular value decomposition (SVD) into two or more principal components, thereby it removes the noise caused by the environment main effects (E) and divide into the two components; genotype effect $(\mathrm{G})$ and genotype $\mathrm{x}$ environment (GE), which have great importance to breeders and agronomists $[12,16,17]$.

\section{RESULTS}

Combined Analysis of Variance indicated statistically significant differences for the genotype, environment and GE, except for yield where GE wasn't significant (Table 2). Significant GE values complicate genotypic selection; however and because the size of GE variation in comparison to G, was significant, we will evaluate the contribution to the total SS and the repeatability of the parameters. Environment was the main contributor $\mathrm{SS}_{\mathrm{E}} \%$ in grain yield and yield components (grain per spike, weight of 1000 grains, and spikes per $\mathrm{m}^{2}$ ) accounting $54.5 \%$ to $77.5 \%$ of the total treatment variation (Table 3). However spikes per $\mathrm{m}^{2}$ and grains per spike were affected less by E, giving values $51.9 \%$ and $54.5 \%$ respectively. Leaf senescence was also highly affected by $\mathrm{E}$ $61.8 \%$ and plant height and lodging were the less affected by $\mathrm{E}$ characters $30.2 \%$ and $15.8 \%$ respectively. Yield and the other characteristics were high repeatable with values ranging from 0.8 to 0.9 indicated the excelled discrimination of the trial locations and the low error variation. With such a very high repeatability values it is possible to make our decisions by simple mean values despite the statistical significant of the GE. Grain yield performance of landraces Skliropetra and M. Argolidas was significantly higher (3380 and $3070 \mathrm{~kg} / \mathrm{ha}$, respectively) and characterized by high number of grains per spike, high number of spikes per $\mathrm{m}^{2}$ and the lower value of $1000 \mathrm{KW}$ (Table 4). The lowest yielding varieties were Mexical 81 and the landrace M.Ait/nias (2400 and $1930 \mathrm{~kg} / \mathrm{ha}$, respectively) characterized by the fewest number of spikes per $\mathrm{m}^{2}$, small number of grains per spike and high weight of 1000 grains. The variety Yecora and the landrace Xylókastro gave medium values for yield (2840 and $2700 \mathrm{~kg} / \mathrm{ha}$, respectively) and characterized by

Table 2. Combined Analysis of Variance for specific characteristics and yield components of wheat landraces grown under organic conditions.

\begin{tabular}{ccccccccc}
\hline & d.f. & Height & $\begin{array}{c}\text { Leaf } \\
\text { Senescence }\end{array}$ & Lodging & $\begin{array}{c}\text { Spikes } \\
\text { per } \mathbf{~ m}^{2}\end{array}$ & Kg /ha & $\begin{array}{c}\text { Weight of } \\
\text { 1000 grains }\end{array}$ & $\begin{array}{c}\text { Grains } \\
\text { per spike }\end{array}$ \\
\hline ENVIRONMENT & 7 & 16681.83 & 101.75 & 28.44 & 800079.55 & 2499772.44 & 5461.41 & 3919.86 \\
GENOTYPE & 5 & 34750 & 17.47 & 101.55 & 299358.22 & 312540.88 & 1297.26 & 1761.17 \\
GXE & 35 & 3879.86 & 45.41 & 49.55 & 442865.77 & 406292.88 & 685.19 & 1501.49 \\
ENVIRONMENT & 7 & 2383.11 & 14.53 & 4.06 & 114297.07 & 357110.34 & 780.20 & 559.98 \\
GENOTYPE & 5 & 6950.13 & 3.49 & 20.31 & 59871.64 & 62508.17 & 259.45 & 352.23 \\
GXE & 35 & 110.85 & 1.29 & 1.41 & 12653.30 & 11608.36 & 19.57 & 42.90 \\
& & & & & & & & \\
ENVIRONMENT & 7 & $19.66^{* * *}$ & $8.86^{* * *}$ & $11.25^{* * *}$ & $4.44^{* *}$ & $17.22^{* * *}$ & $41.07^{* * *}$ & $42.90^{* * *}$ \\
GENOTYPE & 5 & $121.67^{* * *}$ & $4.33^{* *}$ & $68.98^{* * *}$ & $7.65^{* * *}$ & $7.90^{* * *}$ & $53.13^{* * *}$ & $23.50^{* * *}$ \\
GXE & 35 & $1.940^{* *}$ & $1.61^{*}$ & $4.80^{* * *}$ & $1.62^{*}$ & 1.46 & $4.009^{* * *}$ & $2.86^{* * *}$ \\
C.V.\% & & 10.50 & 28.22 & 30.52 & 24.91 & 32.67 & 5.72 & 20.33 \\
\hline
\end{tabular}

*******: Significant at the $0.05,0.01$ and 0.001 , respectively. 
Table 3. Partitioning of Sum of Squares, repeatability indices and probability significance derived by combined analysis of variance for yield and specific characteristics of wheat landraces grown under organic conditions.

\begin{tabular}{cccccccc}
\hline & Yield & Spikes per $\mathbf{m}^{2}$ & Weight of $\mathbf{1 0 0 0}$ grains & Grains per spike & Height & Stay Green & Lodging \\
\hline $\mathbf{S S}_{\mathrm{G}} \%$ & $9.7^{* *}$ & $19.4^{* *}$ & $17.4^{* *}$ & $24.5^{* *}$ & $62.8^{* *}$ & $10.6^{* *}$ & $56.6^{* *}$ \\
$\mathbf{S S}_{\mathrm{E}} \%$ & $77.7^{* *}$ & $51.9^{* *}$ & $73.4^{* *}$ & $54.5^{*}$ & $30.2^{* *}$ & $61.8^{* *}$ & $15.8^{* *}$ \\
$\mathbf{S S}_{\mathrm{GE}} \%$ & $12.6^{\mathrm{NS}}$ & $28.7^{*}$ & $9.2^{* *}$ & $20.9^{* *}$ & $7.0^{* *}$ & $27.6^{*}$ & $27.6^{* *}$ \\
$\mathbf{H}^{2}$ & 0.8 & 0.8 & 0.9 & 0.9 & 1.0 & 1.0 & 0.9 \\
\hline
\end{tabular}

${ }^{* *}$ Value significant for 0.01 probability level; ${ }^{*}$ Value significant for 0.05 probability level; ${ }^{\text {NS }}$ : no significant value.

Table 4. Mean values for yield components and specific characteristics evaluated from 6 wheat genotypes in three environments for three years of experimentation.

\begin{tabular}{|c|c|c|c|c|c|c|c|c|c|c|c|c|c|c|}
\hline \multirow{2}{*}{$\begin{array}{c}\text { Variety } \\
\text { M. AIT/NIAS }\end{array}$} & \multicolumn{2}{|c|}{ Height $\mathbf{c m}$} & \multicolumn{2}{|c|}{$\begin{array}{c}\text { Leaf } \\
\text { Senescence }\end{array}$} & \multicolumn{2}{|c|}{ Lodging・ } & \multicolumn{2}{|c|}{$\begin{array}{l}\text { Spikes } \\
\text { per } \mathbf{m}^{2}\end{array}$} & \multicolumn{2}{|c|}{$\begin{array}{c}\text { Yield } \\
\text { (Kg/ha) }\end{array}$} & \multicolumn{2}{|c|}{$\begin{array}{l}\text { Weight of } 1000 \\
\text { grains (g) }\end{array}$} & \multicolumn{2}{|c|}{$\begin{array}{c}\text { Grains } \\
\text { per spike }\end{array}$} \\
\hline & 90.7 & $\mathrm{a}$ & 2.9 & $\mathrm{~b}$ & 2.6 & $\mathrm{~b}$ & 319 & $\mathrm{~cd}$ & 1930 & d & 41.3 & $\mathrm{a}$ & 14.0 & d \\
\hline SKLIROPETRA & 68.9 & $\mathrm{~b}$ & 2.7 & $\mathrm{~b}$ & 1.3 & $\mathrm{~cd}$ & 422 & $\mathrm{a}$ & 3380 & $\mathrm{a}$ & 34.6 & $\mathrm{c}$ & 21.2 & $\mathrm{~b}$ \\
\hline M. ARGOLIDAS & 62.9 & $\mathrm{c}$ & 3.2 & $a b$ & 1.4 & $\mathrm{c}$ & 339 & $\mathrm{bc}$ & 3070 & $\mathrm{ab}$ & 34.4 & $\mathrm{c}$ & 24.7 & a \\
\hline YECORA & 52.8 & d & 3.7 & $\mathrm{a}$ & 1.0 & $\mathrm{e}$ & 382 & $a b$ & 2840 & $\mathrm{bc}$ & 39.3 & $\mathrm{~b}$ & 17.2 & $\mathrm{c}$ \\
\hline MEXICALI81 & 61.6 & $\mathrm{c}$ & 3.6 & $\mathrm{a}$ & 1.1 & de & 285 & $\mathrm{~d}$ & 2400 & $\mathrm{~cd}$ & 40.4 & $\mathrm{ab}$ & 20.7 & $\mathrm{~b}$ \\
\hline XYLOCASTRO & 95.0 & $\mathrm{a}$ & 2.9 & $\mathrm{~b}$ & 3.2 & $\mathrm{a}$ & 383 & $a b$ & 2700 & $\mathrm{bc}$ & 41.7 & $\mathrm{a}$ & 16.6 & $\mathrm{c}$ \\
\hline Mean & 72.0 & & 3.2 & & 1.8 & & 355 & & 2720 & & 38.6 & & 19.0 & \\
\hline C.V.\% & 10.5 & & 28.2 & & 30.5 & & 24.9 & & 32.7 & & 5.7 & & 20.3 & \\
\hline L.S.D. 0.5 & 4.3 & & 0.5 & & 0.3 & & 50.8 & & 51.1 & & 1.3 & & 2.2 & \\
\hline $\mathrm{F}$ & $* * *$ & & $* *$ & & $* * *$ & & $* * *$ & & $* * *$ & & $* * *$ & & $* * *$ & \\
\hline
\end{tabular}

Leaf Senescence (climax 1 - 9): 1: low senescence, 9: high senescence; ${ }^{\bullet}$ Lodging (climax 1 - 9): 1: no lodging, 9: high lodging.

high number of spikes per area, small number of grains per spike and high weight of 1000 grains. As for other features measured like height, senescence and lodging, it was found that commercial varieties Yecora and Mexicali81, had low values for height and lodging and especially high values for senescence indicated the low adaptability of these varieties and on the other hand the high adaptation of the selected landraces (Table 4). The variance of yield grain due to genotype and GXE interaction-analyzed in two principal components PC1, PC2 - illustrates genotypes and GE effects in the same figure (Figure 1). The analysis was considered satisfactory as the sum of two principal components PC1-PC2 explains $74 \%$ of the total variance due to $\mathrm{G}+\mathrm{GE}$ [12]. In our experiments it was found that landraces Skliropetra and M. Argolidas were characterized by high yield potential and high adaptability as it is indicated by their position in the biplot (further right in the horizontal axis and with small vertical intercept distance) (Figure 1(a)).

The location of Larisa displayed as the higher grain yielding environment through three years of experiment- tation giving very high yield dispite the low inputs of the organic environment (Table 5). Into this environment, the average yield for all varieties at the first growing season (Larisa 05) was $4520 \mathrm{~kg} / \mathrm{ha}$ and $4290 \mathrm{Kg} / \mathrm{ha}$ at the next season (LAR 06), respectively. The lower yield observed in the region of Thessaloniki regardless to genotype and year of experimentation and the location of Kilkis had an intermediate yielding potential. The ideal test environment - depicted theoretically in the center of the concentric circles and characterized as fully representative when it has zero distance from the horizontal axis and giving the maximum discrimination among the cultivar when its vector is the longest (Figure 1(b)). The experimental data showed that close to the ideal proved to be the environment of Larissa in two out of three years and as a second choise for multilocational evaluation proved to be the environment of Kilkis.

As regard to correlation of characteristics it was found that yield was positively correlated with the number of fertile spikes per $\mathrm{m}^{2}$ and negatively with the weight of 1000 grains (Table 6). Positive impact on yield had the 


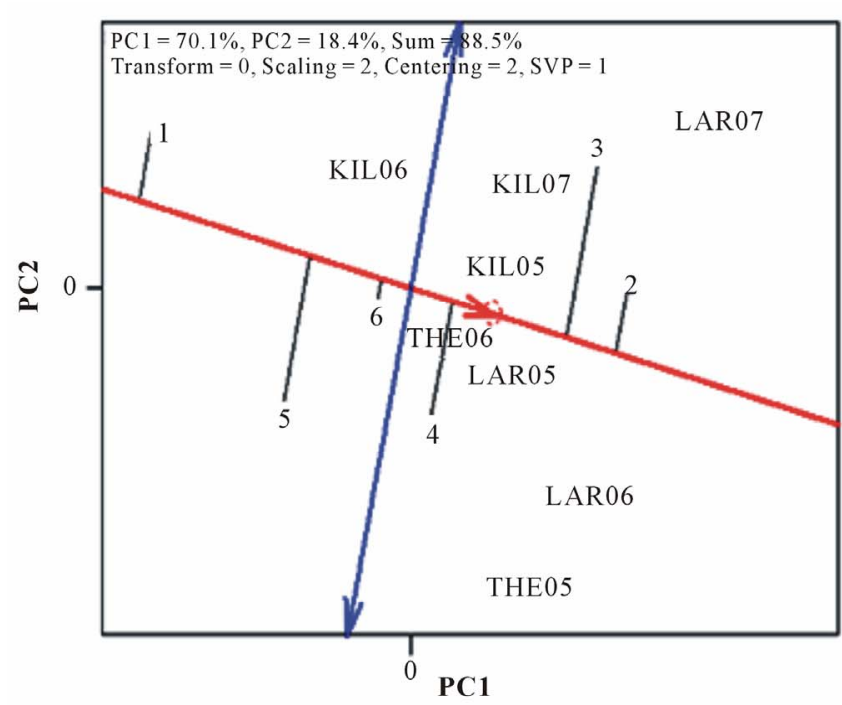

The Average Tester Coordination view

(a)

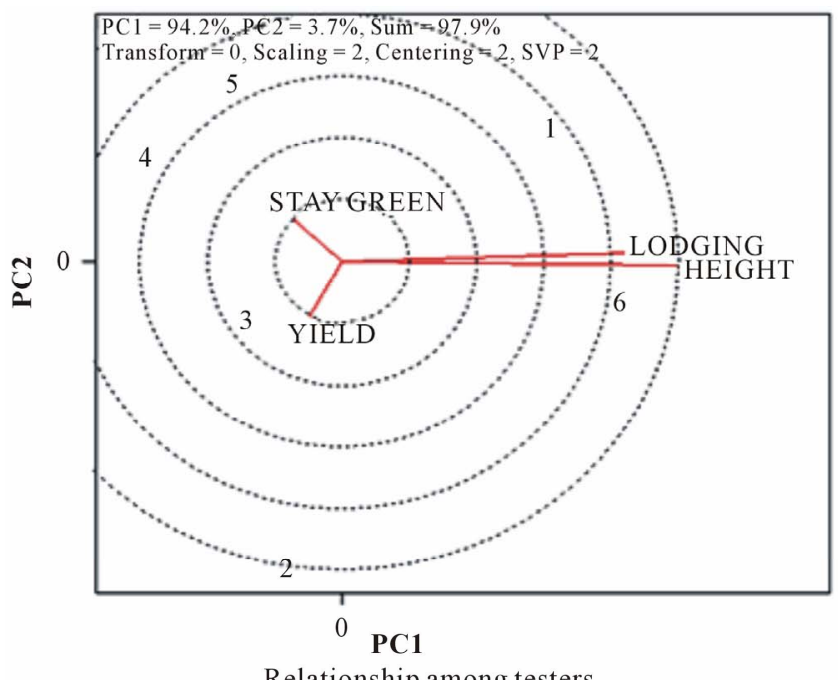

Relationship among testers

(c)

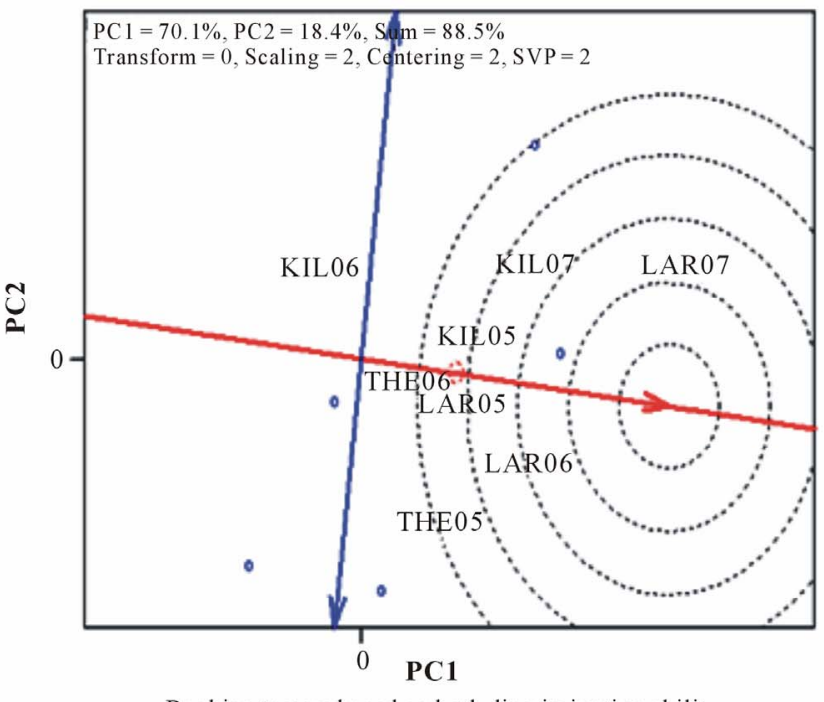

Ranking testers based on both discriminating ability and representativeness

(b)

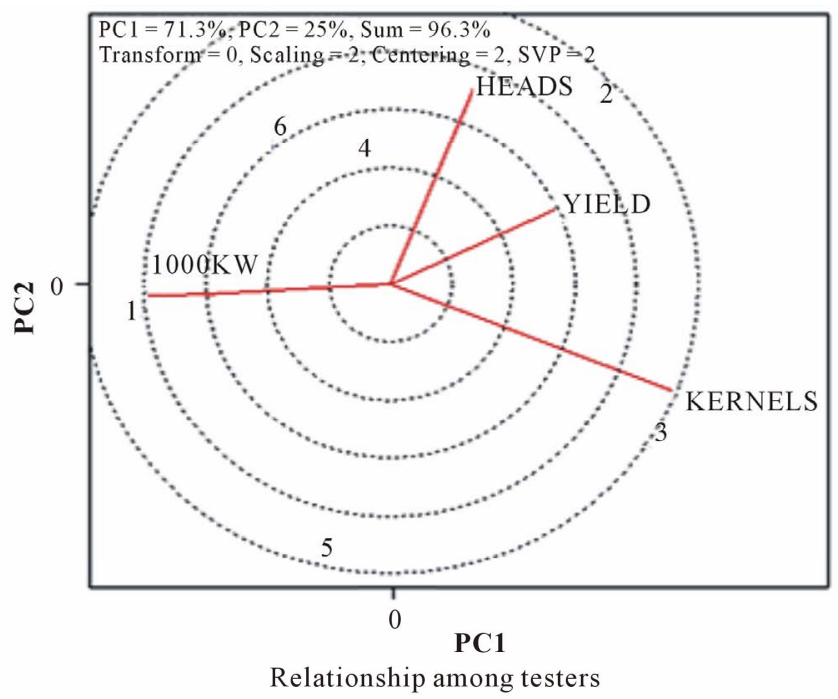

(d)

Figure 1. GGE - biplot analysis, (a) Discrimination of wheat landraces based on yield performance according to interaction environment x year; (b) Proposal for the representative (ideal) environment of experimentation; (c) Correlation between specific characteristics and genotypes; (d) Correlation between yield components and genotypes. GENOTYPES: 1. M. AIT/NIAS, 2. SKLIROPETRA, 3. M.ARGOLIDAS, 4. YECORA, 5. MEXICALLI, 6. XYLOCASTRO; LOCATIONS/Year: KIL/2005-06-07, LAR/005-06-07, THES 05-06.

number of grains per spike. On the other hand, was found negative correlation between yield and plant height which combined with lodging, as expected. Furthermore, strong negative correlation was found among the number of grains per spike and weight of 1000 grains (Table 6).

In Figure 1(c), the correlation between agronomic characteristics of genotypes based on their regional evaluation was presented as well. This correlation is given by the angle between the corresponding vectors from the centre to the point of the feature, on the diagram.
From the graph it is evident that among the characteristics Lodging and Height there is a highly positive correlation (Figure 1(c)). Negative correlation was found between Yield and characteristics Height and Lodging. Negative correlation was also observed for the characteristic Leaf senescence with Lodging and Height and low correlation with the components of Yield. Furthermore, yield performance is the key feature for genotypes Skliropetra that is the winner in both yield and grain per spike, and M. Argolidas that is the winner in Grains $/ \mathrm{m}^{2}$ 
Table 5. Mean total yield over environments for all years of experimentation.

\begin{tabular}{ccc}
\hline Locations x Year & \multicolumn{2}{c}{ Total Yield K/ha } \\
\hline LARISA 05 & 4520 & $\mathrm{a}$ \\
THESSALONIKI 05 & 1230 & $\mathrm{~d}$ \\
KILKIS 05 & 3850 & $\mathrm{~b}$ \\
LARISA 06 & 4290 & $\mathrm{ab}$ \\
THESSALONIKI 06 & 1110 & $\mathrm{~d}$ \\
KILKIS 06 & 1270 & $\mathrm{~d}$ \\
LARISA 07 & 2820 & $\mathrm{c}$ \\
KILKIS 07 & 2680 & $\mathrm{c}$ \\
Mean & 2720 & \\
C.V. $\%$ & 32.7 & \\
L.S.D -0.5 & 59 & \\
Significance & & \\
\hline
\end{tabular}

Means with the same letter ( $a, b, c$...) within a column, are not significantly different at $5 \% ;{ }^{*},{ }^{* *},{ }^{* * *}$ Significant at the $0.05,0.01$ and 0.001 , respectively.

(Figure 1(d)). On the other hand Mexicali81 and Yecora were suffered by high Leaf senescence and landrace Xylocastro by lodging because of its high stature.

\section{DISCUSSION}

In the present study, the best varieties in terms of yield were the landraces Skliropetra and M. Argolidas characterized by the lowest weight of 1000 grains, large number of spikes per square meter and the highest number of grains per spike as compared to the mean values. The results are in accordance with various studies which have revealed the positive impact of increased number of spikes per area on yield [18-21] and the number of grains per spike $[18,22,23]$. On the contrary, our results did not confirm studies claiming that higher yields are combined with increased 1000 kernel weight [5,24]. Other researchers suggested that higher yield in modern varieties was combined with low 1000 kernel weight $[22,25]$. In our study it was found that commercial varieties Yekora and Mexicali 81 indicated higher values for leaf sensecence at blooming stage as compared to landraces. This observation is in an agreement with other studies supported that old varieties have a delay in leaf senescence [26] while modern varieties probably are more susceptible to leaf senescence during various stresses [27,28]. This specific trait could be proved very useful for wheat breeding. Acevedo [29] concluded that any increase of grain yield in barley under dry-land conditions was significantly correlated with delayed leaf senescence while Thomas and Smart [30] have argued that healthy stay green plants produce higher yield and this behavior could be an alternative for water stress environments (Araus et al. [31]).

Finally, our results confirmed argues that modern varieties due to their low stature are more resistant to lodging [32]. Height has been correlated with low yield [33] as our results confirmed. Nevertheless many researchers claim that varieties with high stature plants can compete the weeds, and are more suitable for organic agriculture $[34,35]$. The varieties of the highest yield in our experiments were landraces with intermediate to high stature thereby confirming previous reports.

\section{GGE-Bi Plot Analysis}

This analysis demonstrates that GGE biplot is a useful tool for the analysis of multienvironmental trials in organic conditions for wheat cultivation. Based on a drawnto-scale, two dimensional GGE biplot, the similarities and differences among environments and their discrimination of the genotypes, the similarities among the wheat genotypes in their response to the environments, and the nature and magnitude of interaction between any genotype and any environment can be readily visualized. Moreover, by adding some supplemental lines to the biplots,

Table 6. Phenotypic coefficients of correlation (r) between grain yield, yield components and agronomic parameters.

\begin{tabular}{|c|c|c|c|c|c|c|c|}
\hline TRAIT & Height & Leaf Senescence & Lodging & Spikes per $\mathbf{m}^{2}$ & Yield & Weight of 1000 grains & Grains per spike \\
\hline Height & 1 & & & & & & \\
\hline Leaf Senescence & -0.733 & 1 & & & & & \\
\hline Lodging & 0.968 & -0.623 & 1 & & & & \\
\hline Spikes per $\mathbf{m}^{2}$ & 0.021 & -0.446 & 0.065 & 1 & & & \\
\hline Yield & -0.446 & -0.125 & -0.405 & 0.728 & 1 & & \\
\hline Weight of 1000 grains & 0.499 & 0.156 & 0.540 & -0.393 & -0.812 & 1 & \\
\hline Grains per spike & -0.586 & 0.166 & -0.588 & 0.011 & 0.686 & -0.819 & 1 \\
\hline
\end{tabular}


the best cultivars and their respective environments of experimentation become evident.

In our experiments variation in grain yield was mainly affected by genotype and genotype $x$ environment interactions. These two sources of variation explained the $88.5 \%$ of the total variance. The results of analysis by the GGE-Biplot showed that genotypes Skliropetra, M. Argolidas over-yielded the mean average of all wheat varieties tested in this experiment. These two varieties, in the present investigation, identified as the most consistent-performing varieties. The use of these varieties by the growers would be ensure stable performance across years. These varieties could also be used in a breeding program to develop new consistent-performing varieties. Moreover genotypes Skliropetra and M. Argolidas were characterized by high yield potential and high adaptability. Weber et al. [36] underlined that breeders seek for stable varieties in various environments but for organic agriculture it is argued whether biological stability is so important or the compromise between agronomic and biological stability. Yan and Kang [37] defined an ideal genotype as one that has the highest mean yield and is also absolutely stable. This means that the ideal genotype has the highest and identical yield in all tested environments.

Information on performance stability is important when a significant genotype-by-environment (GE) interaction is detected in yield trials [38]. The same researchers confirmed that GGE Bi plot Analysis can be used effectively in variety trials, whether or not GXE interaction is significant. In our experiments for all characteristics GXE interaction was significant except for yield.

The experimental data by GGE biplot analysis showed that the environment of Larissa was proved very close to the ideal in two out of three years of experimentation and the environment of Kilkis as a second choice for multilocation evaluation. This conclusion was confirmed also by the results from analysis of variance (ANOVA). The ranking of cultivars along to the environments tested; based on ANOVA and GGE Biplot gave similar results through all years of experimentation. The ideal environment is one of the most discriminating of genotypes and is more representative for all tested environments. For this reason GGE biplot proved to be more informative giving high resolution and revealing the best combination between genotype and environment. Therefore is deemed suitable for the evaluation of wheat varieties under organic environment of experimentation.

Similar conclusions we can address about correlations among traits from GGE biplot analysis and ANOVA. Yield (performance) was founded as a key feature for genotypes M. Argolidas and Skliropetra. Yield was correlated with number of spikes per $\mathrm{m}^{2}$, kernels per spike and negatively with height and lodging. Therefore, selection based on these features should be lead to an increased yield in the target organic environment of selection. As an advantage of GGE biplot analysis, is the more representative way to indicate the main feature for each cultivar.

From the results it is evident that the characteristics lodging and height were correlated positively but each one had negative correlation with yield. These results confirmed that modern varieties due to their low stature are more resistant to lodging $[32,39]$. Nevertheless many researchers claim that varieties with high stature plants can compete better with weeds, and are more suitable for organic agriculture [34].

Finally, yield was positively correlated with the number of fertile ear per surface and negatively with the weight of 1000 grains. A negative relationship between grain number per unit land area and the average weight of these grains has frequently been found [40].

\section{CONCLUSIONS}

The multienvironment evaluation demonstrated that the program for selection of high yield and adaptable landraces suitable for organic environment was successful. Two landraces were selected with proven high yield potential and adaptation under organic environment. These landraces could be used directly as dynamic populations or after further improvement and selection as pure lines or as parental lines for the development of new wheat varieties suitable for organic farming.

GGE biplot analysis was shown to be more informative than ANOVA for distinguishing some special features in specific cultivars as expressed in different environments. This statistical model was found to be suitable for experimentation for wheat landraces when grown under organic environment.

\section{REFERENCES}

[1] Atkinson, M., Kettlewell, P.S., Poulton, P.R. and Hollings, P.D. (2008) Grain quality in the Broadbalk wheat experiment and the winter North Atlantic oscillation. Journal of Agricultural Science, 146, 541-549. doi: $10.1017 / \mathrm{S} 0021859608007958$

[2] Gitay, H., Brown, S., Easterling, W. and Jallow, B. (2001) Ecosystems and their goods and services. In: McCarthy, J.J., Canziani, O.F., Leary, N.A., Dokken, D.J. and White, K.S., Eds., Climate Change 2001: Impacts, Adaptation, and Vulnerability. Contribution of Working Group II to the Third Assessment Report of the Intergovernmental Panel on Climate Change, Cambridge University Press, Cambridge, 237-342.

[3] Parry, M.L., Rosenzweig, C., Iglesias, A., Livermore, M. and Fischer, G. (2004) Effects of climate change on global food production under SRES emissions and socio- 
economic scenarios. Global Environmental Change, 14, 53-67. doi:10.1016/j.gloenvcha.2003.10.008

[4] Annicchiarico, P. and Pecetti, L. (1993) Contribution of some agronomic traits to durum wheat performance in a dry Mediterranean region of Northern Syria. Agronomie, 13, 25-34. doi:10.1051/agro:19930102

[5] Pecetti, L., Boggini, G, and Gorham, J. (1994) Performance of durum wheat landraces in a Mediterranean environment (eastern Sicily). Euphytica, 80, 191-199. doi:10.1007/BF00039650

[6] Wolfe, M.S., Baresel, J.P., Desclaux, D., Goldringer, I., Hoad S., Kovacs, G., Löschenberger, F., Miedaner, T., Østergård, H. and Lammerts van Bueren, E.T. (2008) Developments in breeding cereals for organic agriculture. Euphytica, 163, 323-346. doi:10.1007/s10681-008-9690-9

[7] Hammer, K. and Gladis, T.H. (2001) Nutzung genetischer ressourcen-ökologischer wert der biodivesität. Symposium der AG Genetische Ressourcen der Gesellschaft fur Pflanzenzuchtung, 23-24 November 2000, Witzenhausen, Schriften zu Genetischer Ressoursen 16, ZADI, Bonn.

[8] Lammerts van Bueren, E.T., van Soest, L.J.M., de Groot, E.C., Boukema, I.W. and Osman, A.M. (2005) Broadening the genetic base of onion to develop better-adapted varieties for organic farming systems. Euphytica, 146, 125-132. doi:10.1007/s10681-005-0204-8

[9] Moragues, M., Garcia del Moral, L.F., Moralejo, M. and Royo, C. (2006) Yield formation strategies of durum wheat landraces with distinct pattern of dispersal within the Mediterranean basin. I. Yield components. Field Crops Research, 95, 194-205. doi:10.1016/j.fcr.2005.02.009

[10] Ceccarelli, S. (1989) Wide adaptation. How wide? Euphytica, 40, 197-205.

[11] Cooper, M., Podlich, D.W., Luo, L. (2007) In: Varshney, R. and Tuberosa, R., Eds., Modeling QTL Effects and MAS in Plant Breeding. Genomics-Assisted Crop Improvement, Springer, Dordrecht, The Netherlands, 1, 57-96.

[12] Yan, W. and Hunt L.N. (2001) Interpretation of Genotype $\mathrm{X}$ Environment Interaction for Winter Wheat Yield in Ontario. Crop Science, 41, 19-23. doi:10.2135/cropsci2001.41119x

[13] Koutis, K. and Galanopoulou-Sendouka, St. (2005) Suitability of local varieties of wheat to organic agricultural systems. Proceedings of International Symposium on: Organic Agriculture in the Mediterranean-Problems and Perspectives, Chania, 9-11 November 2005.

[14] Anonymous (1991) Council Regulation (EEC) No 2092/91 on organic production of agricultural products and indications referring thereto on agricultural products and foodstuffs including all amendments. Official Journal No L 198, 22.7.1991, European Economic Community, Brussels, Belgium.

[15] Guillen-Portal, F.R., Russel, W.K., Eskridge, K.M., Baltensperger, D.D., Nelson, L.A., D'Croz-Mason, N.E. and Johnson, B.E. (2004) Selection environments for maize in the U.S. western high plains. Crop Science, 44, 1519-1526. doi:10.2135/cropsci2004.1519
[16] Yan, W. (2001) GGE biplot-a Windows application for graphical analysis of multi-environment trial data and other types of two-way data. Agronomy Journal, 93, 1-11. doi:10.2134/agronj2001.9351111x

[17] Yan, W. and Rajcan, I. (2002) Biplot analysis of test sites and trait relations of soybean in Ontario, Crop Science, 42, 11-20. doi:10.2135/cropsci2002.0011

[18] Calderini, D.F., Dreccer, M.F. and Slafer, G.A. (1995) Genetic improvement in wheat yield and associated traits. A re-examination of previous results and the latest trends. Plant Breeding, 114, 108-112. doi:10.1111/j.1439-0523.1995.tb00772.x

[19] Feil, B. (1992) Breeding progress in small grain cereals-A comparison of old and modern cultivars. Plant Breeding, 108, 1-11. doi:10.1111/j.1439-0523.1992.tb00093.x

[20] Reynolds, M.P., Balota, M., Delgado, M.I.B., Amani, I. and Fischer, R.A. (1994) Physiological and morphological traits associated with spring wheat yield under hot, irrigated conditions. Australian Journal of Plant Physiology, 21, 717-730. doi:10.1071/PP9940717

[21] Garcia del Moral, L., Rharrabti, Y., Villegas, D. and Royo, C. (2003) Evaluation of grain yield and its components in durum wheat under mediterranean conditions: An ontogenic approach. Agronomy Journal, 95, 266-274. doi:10.2134/agronj2003.0266

[22] Perry, M. and D'Antuono, M. (1989) Yield improvement and associated characteristics of some Australian spring wheat cultivars introduced between 1860 and 1982. Australian Journal of Agricultural Research, 40, 457-472.

[23] Siddique, K., Belford, R., Perry, M. and Tennant, D. (1989) Growth, development and light interception of old and modern wheat cultivars in a Mediterranean-type environment. Australian Journal of Agricultural Research, 40, 473-487.

[24] Cox, T., Shroyer, J., Ben-Hui, L., Sears, R. and Martin, T. (1988) Genetic improvement in agronomic traits of hard red winter wheat cultivars from 1919 to 1987. Crop Science, 28, 756-760.

doi:10.2135/cropsci1988.0011183X002800050006x

[25] Waddington, S., Ransom, J., Osmanzai, M. and Saunders, D. (1986) Improvement in the yield potential of bread wheat adapted to Northwest Mexico. Crop Science, 26, 698-703.

doi:10.2135/cropsci1986.0011183X002600040012x

[26] Hafsi, M., Mechmeche, W., Bouamama, L., Djekoune, A., Zaharieva1, M. and Monneveux, P. (2000) Flag leaf senescence, as evaluated by numerical image analysis, and its relationship with yield under drought in durum wheat. Journal of Agronomy and Crop Science, 185, 275-280. doi:10.1046/j.1439-037x.2000.00436.x

[27] Slafer, G.A. and Andrade, F.H. (2003) Physiological attributes to the generation of grain yield in bread wheat cultivars released at different eras. Field Crops Research, 31, 351-367. doi:10.1016/0378-4290(93)90073-V

[28] Austin, R.B., Ford, M.A. and Morgan, C.L. (1989) Genetic improvement in the yield of winter wheat: A further evaluation. Journal of Agriculture Science, 112, 295-301. 


\section{doi:10.1017/S0021859600085749}

[29] Acevedo, E. (1987) Assessing crop and plant attributes for cereal improvements. In: Srivastava, J.P., Porceddu, E., Acevedo, E. and Varma, S., Eds., Drought Tolerance in Winter Cereals, Chichester, UK, Willey, 303-320.

[30] Thomas, H. and Smart, C.M. (1993) Crops that stay green. Annals of Applied Biology, 123, 193-129. doi:10.1111/j.1744-7348.1993.tb04086.x

[31] Araus, J.L., Bort, J., Steduto, P., Villegas, D. and Royo, C. (2003) Breeding cereals for mediterranean conditions: Ecophysiological clues for biotechnology application. Annals of Applied Biology, 142, 129-141. doi:10.1111/j.1744-7348.2003.tb00238.x

[32] Anderson, M.K. and Reinbergs, E. (1985) Barley breeding. In: Rasmusson, D.C. Ed., Barley Breeding, Monograph 26, ASA-CSSA Madison, WI 53711-USA, 231268.

[33] Donmez, E., Sears, R., Shroyer, J. and Paulsen, G. (2001) Genetic gain in yield attributes of winter wheat in the Great Plains. Crop Science, 41, 1412-1419. doi:10.2135/cropsci2001.4151412x

[34] Hoad, S.P. and Topp, C.F.E. (2007) Quantifying genotype and environment interactions to benefit selection and evaluation of cereals for competitiveness against weeds. In: Lammerts van Bueren, E.T., Goldringer, I., Scholten, O. and Østergård, H., Eds., Proceedings of Eucarpia Symposium of Working Group in Organic Plant Breeding, Wageningen, Netherlands, 7-9 November 2007, 72 Pages.

[35] Legzdina, L., Kokare, A. and Lammerts van Bueren, E.
(2007) Genotype and environment interaction of various spring barley genotypes in organic and conventional growing conditions. In: Lammerts van Bueren, E.T., Goldringer, I., Scholten, O. and Østergård, H., Eds., Proceedings of Eucarpia Symposium of Working Group Organic Plant Breeding, Wageningen, Netherlands, 7-9 November 2007, 17 Pages.

[36] Weber, W., Wricke, G. and Westermann, T. (1996) Selection of genotypes and prediction of performance by analysing Genotype-by-Environment interactions. In: Kang, M. and Gauch, H., Eds., Selection of Genotypes and Prediction of Performance by Analysing Genotype-by-Environment interactions. Genotype-by-Environment Interaction, CRC Press, Boca Raton, Florida, USA, 353-371.

[37] Yan, W. and Kang, M.S. (2003) GGE Biplot analysis. CRC Press, Boca Raton.

[38] Bhan, M.K., Pal, S., Rao, B.L., Dhar, A.K. and Kang, M.S. (2005) GGE biplot analysis of oil yield in lemongrass (Cymbopogon spp.). Journal of New Seeds, 7, 127 139. doi:10.1300/J153v07n02_07

[39] Law, C.N. (1995) Genetic manipulation in plant breedingprospects and limitations. Euphytica, 85, 1-12. doi:10.1007/BF00023925

[40] Slafer, G.A., Calderini, D.F. and Miralles, D.J. (1996). Increasing yield potential in wheat: Breaking the barriers. In: Reynolds, M., Ed., Proceedings of CIMMYT International Symposium: Generation of Yield Components and Compensation in Wheat: Opportunities for Further Increasing Yield Potential, CIMMYT, Mexico, 101-133. 